\title{
Is It Still Necessary to Continue to Collect Crop Genetic Resources in the Mediterranean Area? A Case Study in Catalonia
}

\author{
J. Casals, 1雨
}

Email j.casalsmissio@gmail.com

F. Casañas, 1,2

J. Simó, 1

1 Miquel Agustí Foundation, Campus del Baix Llobregat, Carrer Esteve Terrades 8, 08860 Castelldefels, Spain AQ1

2 Department of Agri-Food Engineering and Biotechnology, Polytechnic University of Catalonia, Campus del Baix Llobregat, Carrer Esteve Terrades 8, 08860 Castelldefels, Spain

\section{Abstract}

Is It Still Necessary to Continue to Collect Crop Genetic Resources in the Mediterranean Area? A Case Study in Catalonia Crop genetic resources have been extensively collected in Europe in the last century, creating large, publicly available ex situ collections. While this huge genetic diversity is often underutilized, in recent decades, several initiatives have emerged at the local level to collect germplasm cultivated on farm. Uncoordinated actors often carry out these collecting missions without considering previously collected data. To explore whether new collecting missions are likely to be worthwhile, we studied the crop genetic resources conservation network in Catalonia by analyzing the passport data and geographical distribution of germplasm stored in seed banks. Moreover, to determine whether this germplasm was representative of the diversity cultivated on farm, we performed new collecting missions in four randomly selected areas in the European Union's Natura 2000 network and compared the results with the ex situ databases. Seed banks currently hold a large germplasm collection (2931 accessions), although most materials are conserved in private collections without regulated systems for 
seed regeneration and are not present as duplicates in the National Inventory. One important shortcoming of the ex situ network is that the germplasm conserved ex situ shows a low geographical coverage, representing only $35.3 \%$ of the municipalities in Catalonia. Our new missions allowed us to collect 234 accessions, mostly tomatoes (17.5\%) and beans (16.2\%). The ecological indicators' richness (both at species (S) and variety (V) levels), total abundance (A), and the Shannon-Weaver diversity index calculated at species (H2, considering the different accessions of each variety as a single population) and variety levels ( $\mathrm{H} 3$, considering the intra-varietal genetic diversity) were higher in the newly collected germplasm than in the ex situ collections, suggesting that seed banks do not accurately represent the genetic diversity still cultivated on farm. Moreover, some important landraces from each area were absent or underrepresented in the ex situ collections. Thus, it is necessary to continue to devote efforts to collecting germplasm; better organization between actors and targeting specific species/varieties can increase the efficiency of new collecting missions. As a conclusion, we propose different criteria to guide new missions and to improve the network's conservation activities.

AQ2

\section{Key Words}

\section{Landrace}

horticultural crops

agrobiodiversity

ex situ conservation

on-farm conservation

germplasm bank

ethnobotany.

\section{Introduction}

Conservation of crop genetic resources (CGR) is one of the most important challenges that agriculture has faced in the last century. CGR are essential for agricultural resilience and sustainability and can play a key role in adapting crops to changing climates (Gepts 2006). In the last century, agricultural ecosystems and production methods changed drastically, leading to the replacement of historically cultivated varieties by modern varieties with higher performances (van de Wouw et al. 2010) and the loss of many varieties (i.e., genotypes). In Europe, it is estimated that 70 to $100 \%$ of the genotypes have been lost, depending on the crop and the area studied (reviewed by Hammer and Teklu (2008)). The international community reacted to this threat to 
sustainability, promoting the International Treaty on Plant Genetic Resources for Food and Agriculture [ http://www.fao.org/plant-treaty/en/ ] (verified 6 December 2016).

In parallel, efforts have been made to conserve CGR by collecting landraces (i.e., varieties characterized by distinctive agromorphological traits and linked to traditional dishes in their areas of origin) (Zeven 1998), (old) folk varieties (Berg 2009), underutilized crops (Galluzzi and López Noriega 2014), and crop wild relatives (Maxted et al. 2007). Initially, the strategy was to collect the maximum genetic diversity in as many ecogeographical areas as possible, accumulating a large number of accessions in seed banks. In recent years, scientist have started to review this huge amount of information, compiling data from different collection missions in attempt to understand genetic richness and improve passport data (Tanksley and McCouch 1997; Thomas et al. 2012; Thormann et al. 2012), developing new collection missions to collect specific landraces still not present in the ex situ collections (Laghetti et al. 2005), documenting the degree of actual on farm conservation (Jarvis et al. 2008; Montesano et al. 2012; Portis et al. 2012), and comparing data from different collection expeditions to estimate genetic erosion (Hammer et al. 1996; Hammer and Laghetti 2005). Promoting in situ conservation (preservation of traditional agrosystems and empowerment of farmer networks that conserve seeds) in combination with ex situ conservation tools has proven the best strategy to preserve genetic diversity and maintain its evolution (Gepts 2006).

Molecular technologies offer promising tools to understand what is filed in seed banks, rationalize the germplasm collections, and detect genetic variants with agronomic interest (Prada 2009). Meanwhile, germplasm collection missions continue to be conducted in scarcely studied areas, but also in areas where collection activity has been intense in the last 70 years. This implies that important financial resources are still devoted to collecting CGR, so it is worth analyzing whether new expeditions in certain areas make sense. This will enable stakeholders and scientists to make decisions about what is still necessary to collect from where and about what should be conserved. Furthermore, various actors (governments, universities, nonprofit organizations, and botanical gardens) are involved in CGR conservation, and it is important to understand their relative contributions to CGR conservation to increase the efficiency of this network.

The Mediterranean basin is remarkable for its CGR (Veteläinen and Maxted 2009). In addition to being the original site of some domestications, the basin has been a hotspot for the introduction and diversification of new crops and is considered a secondary center of diversification for many crop species (Hancock 
2004). The co-evolution of both native and newly introduced crops with the diversity of agrosystems and food cultures found in this area, directed by farmer "field plant breeding," has originated a wide diversity of (old) folk varieties and local landraces. Although genetic erosion has drastically diminished the genetic variability, a significant diversity of forms is still present, mostly in nonintensive agrosystems managed by old farmers (Calvet-Mir et al. 2011; Montesano et al. 2012). Some landraces, mainly those with distinctive morphological traits and sensory profiles, are still produced in large quantities to sell in the markets.

Catalonia, in NE Spain, has a surface area of $31,895 \mathrm{~km}^{2}$ and 3 climate types (Mediterranean, alpine, and oceanic). Agricultural activity has been historically important in this region, covering at present $36 \%$ of the surface area. Catalonia is rich in CGR, with many references to landraces found in cookbooks and agricultural books, and some of these landraces are economically important (e.g., "Calçot de Valls" (Allium cepa L.) (Simó et al. 2012), "Penjar" tomato (Solanum lycopersicum L.) (Casals et al. 2012), or "Ganxet" bean (Phaseolus vulgaris L.) (Casañas et al. 1999)). Significant efforts have been made to collect local germplasm, with a National Spanish Inventory hosting hundreds of accessions from this area [ http://wwwx.inia.es/coleccionescrf/ ] (verified 6 May 2016). Boosted by increasing social awareness of the threats of genetic erosion, in recent years, several CGR-conservation initiatives have emerged at the local level, mainly aiming to use this agrobiodiversity to enhance the distinctiveness of local activities (both agriculture and food services). However, rather than taking advantage of previously collected germplasm, new collecting missions have been undertaken, mainly with funding from regional administrations without involving agricultural institutions, so the priorities and outcomes of these missions have been haphazard. For these reasons, Catalonia is a good place to analyze the activities around CGR conservation to examine how the efficiency of CGR conservation networks might be improved. Thus, we analyzed the genetic richness of ex situ collections and the relative contribution of each actor involved in CGR conservation. Furthermore, we carried out an experiment in four areas to estimate whether new germplasm collecting missions are still necessary.

\section{Materials and Methods}

\section{Analysis of the Ex Situ Conservation Network in Catalonia}

To compile information about CGR previously collected in Catalonia and conserved ex situ, we screened the National Inventory of Genetic Resources at the Instituto Nacional de Investigaciones Agrarias (INIA) to identify accessions of horticultural species (i.e., vegetables, pulses, and condiments) from the area of 
study. In Catalonia, nonprofit organizations have carried out several initiatives at the local level to collect and conserve CGR. Data from these local banks were also obtained through personal interviews with germplasm managers (Esporus (Manresa), Les Refardes-Gaiadea (Mura), EcoLlavors (Girona), and SIGMA (Olot)). Furthermore, data from collections held by botanical gardens (Jardí Botànic Marimurtra (Blanes)) and Universities (University of Lleida (UdL) and Polytechnic University of Catalonia-Miquel Agustí Foundation (UPC)) were also included in the study. To enable joint analysis, we entered all data in a single database, standardizing the information from the different germplasm banks (name of the varieties, name of the municipalities, etc.). All institutions were also asked about complementary activities beyond collecting (characterization, seed regeneration, and supplying).

To analyze passport data using geographic information systems (GIS), each collecting site (name of the municipality) was associated with its corresponding geographic coordinates. To study the spatial distribution of ex situ germplasm collections, we constructed a datasheet with the total number of accessions per municipality. Geographical analysis was performed using ArcGIS ${ }^{\circledR}$ software by Esri.

\section{Study in Four Natura 2000 Areas to Evaluate the Efficiency of Prior Collection Missions}

\section{Identification of Collecting Sites}

Rather than using passport data from ex situ collections, to evaluate the efficiency of previous germplasm collection missions, we used the European Union's Natura 2000 network as a neutral matrix for CGR accessions. Sites protected under Natura 2000 are distributed throughout the territory and represent a great diversity of ecosystems, most of which are closely interrelated to agricultural activity (Ostermann 1998). In Catalonia, 963,035 ha of land (30\% of the total area of the region) is protected under Natura 2000. We chose four sites in different areas of Catalonia that represent different ecosystems: ES5110015 (Sistema prelitoral central), ES5140011 (Sistema prelitoral meridional), ES5140019 (Riu Gaià), and ES5130029 (Serres de Queralt i Els Tossals-Aigua d'Ora), all together 83,022 ha, of which 5000 ha are occupied by agriculture. ES5110015 is an inland mountainous area in the center of Catalonia where cereals are the major crop; this site includes territories from 21 municipalities with 37,962 inhabitants. ES5140011 is an inland mountainous area in southern Catalonia where non-irrigated fruit trees are the major crop; this site includes territories from 24 municipalities with 78,146 inhabitants. ES5140019 is a coastal mountainous area in the center of Catalonia where non-irrigated fruit trees and vineyards are the major crops; this site includes territories from 13 
municipalities with 16,483 inhabitants. Finally, ES5130029 is a mountainous area in the foothills of the Pyrenees in northern Catalonia where cereals are the major crop; this site includes territories from 8 municipalities with 7842 inhabitants. The main habitats present in ES5110015, ES5140011, and ES5140019 sites are Mediterranean pine forests with endemic Mesogean pines, while in ES5130029 the main habitats are sub-Mediterranean pine forests with endemic black pines.

\section{New Collecting Missions}

New collecting missions were carried out during 2011 in all the municipalities in each selected Natura 2000 site. To identify farmers who might be preserving traditional seeds, we contacted managers of cooperatives and other agricultural institutions (e.g., syndicates) and technicians from local administrations prior to field surveys. Field surveys lasted at least 3 days in each municipality. To collect information during the interviews with farmers, we adapted the passport registration form proposed by the On-farm Conservation and Management Working Group (European Cooperative Programme for Crop Genetic Resources) ([ http://www.ecpgr.cgiar.org/working-groups/on-farm-conservation/ ] (verified 5 December 2016)). The form includes sociological information about the germplasm owner (age, work), the seeds provided (name of the variety, antiquity, main uses, and recent exchanges of seeds with other farmers), and geographic coordinates of the collecting site.

\section{Data Analysis}

To compare ex situ accessions conserved in germplasm banks with the accessions collected in our new missions, we adapted the ecological indicators proposed by Montesano et al. (2012) for existing databases and databases generated in the new collecting expeditions at each Natura 2000 site: species richness (S, number of collected species); variety richness ( $\mathrm{V}$, number of collected varieties); and total abundance (A, number of collected accessions). To calculate the degree of agrobiodiversity preserved by each system, we employed the Shannon-Weaver index, calculated using the formula $\mathrm{H}=-\Sigma p_{\mathrm{i}} \ln \left(p_{\mathrm{i}}\right)$, where $p_{\mathrm{i}}$ is the proportion of the $i$-th category on the total number of categories. As we had no prior information regarding the genetic integrity of each accession (no molecular or phenotyping data was available to study the genetic distance between accessions of the same variety), we used several approaches in order to calculate the index: (a) H1, considering species as the main category and accessions within species as the individuals used to evaluate the genetic diversity; (b) H2, considering species as the main category and varieties as the individuals used to estimate the diversity within species; and c) H3, considering the variety as the main category 
and accessions within each variety as the individuals used to evaluate the genetic diversity.

To identify significant differences between datasets, we performed analysis of variance (ANOVA) using the SAS statistical package (SAS Institute Inc. 1999).

\section{Results}

\section{The Ex Situ Network}

We identified 3568 accessions in germplasm banks: 1446 in the National Inventory and 2122 in other public and private collections (Table 1). However, $637(27.9 \%)$ accessions in other public and private collections were duplicated in the National Inventory according to passport data, so there were 2931 unique accessions. The largest collection of accessions was the National Inventory $(n=1446)$, followed by universities $(n=1280)$ and nonprofit organizations $(n=824)$; botanical gardens conserved few accessions $(n=18)$. Tomatoes and dry beans were the most represented species, accounting for 1655 (56.5\%) unique accessions conserved ex situ (Fig. 1). Other species with more than 100 accessions were different cultivar-groups of Brassica oleracea L., lettuces (Lactuca sativa L.), and peppers (Capsicum annuum L.). On the other hand, very few accessions of some historically important species were conserved ex situ; for example, there were only 6 accessions of carrots (Daucus carota L.), 5 of garlic (Allium sativum L.), and 5 of cardoon (Cynara cardunculus L.).

\section{Table 1.}

ANALYSIS OF THE EX SITU GERMPLASM CONSERVATION SYSTEM IN CATALONIA.

\begin{tabular}{|l|l|l|l|l|}
\hline $\begin{array}{l}\text { Germplasm } \\
\text { collection }\end{array}$ & $\begin{array}{c}\text { Number } \\
\text { of } \\
\text { accessions }\end{array}$ & $\begin{array}{c}\text { Unique } \\
\text { accessions }\end{array}$ & $\begin{array}{c}\text { Duplicates from } \\
\text { other public and } \\
\text { private collections }\end{array}$ & $\begin{array}{c}\text { Accessions with } \\
\text { information about } \\
\text { collecting site }\end{array}$ \\
\hline $\begin{array}{l}\text { National } \\
\text { Inventory }\end{array}$ & 1446 & 809 & 637 & $94.6 \%$ \\
\hline $\begin{array}{l}\text { Public- } \\
\text { private } \\
\text { collections }\end{array}$ & 2122 & 2122 & - & $83.0 \%$ \\
\hline TOTAL & 3568 & 2931 & 637 & $86.3 \%$ \\
\hline $\begin{array}{l}\text { aNational Inventory (INIA); public-private collections: data from germplasm banks } \\
\text { held by universities, botanical gardens, and nonprofit organizations }\end{array}$
\end{tabular}

Fig. 1.

Distribution by species in the ex situ collections. 


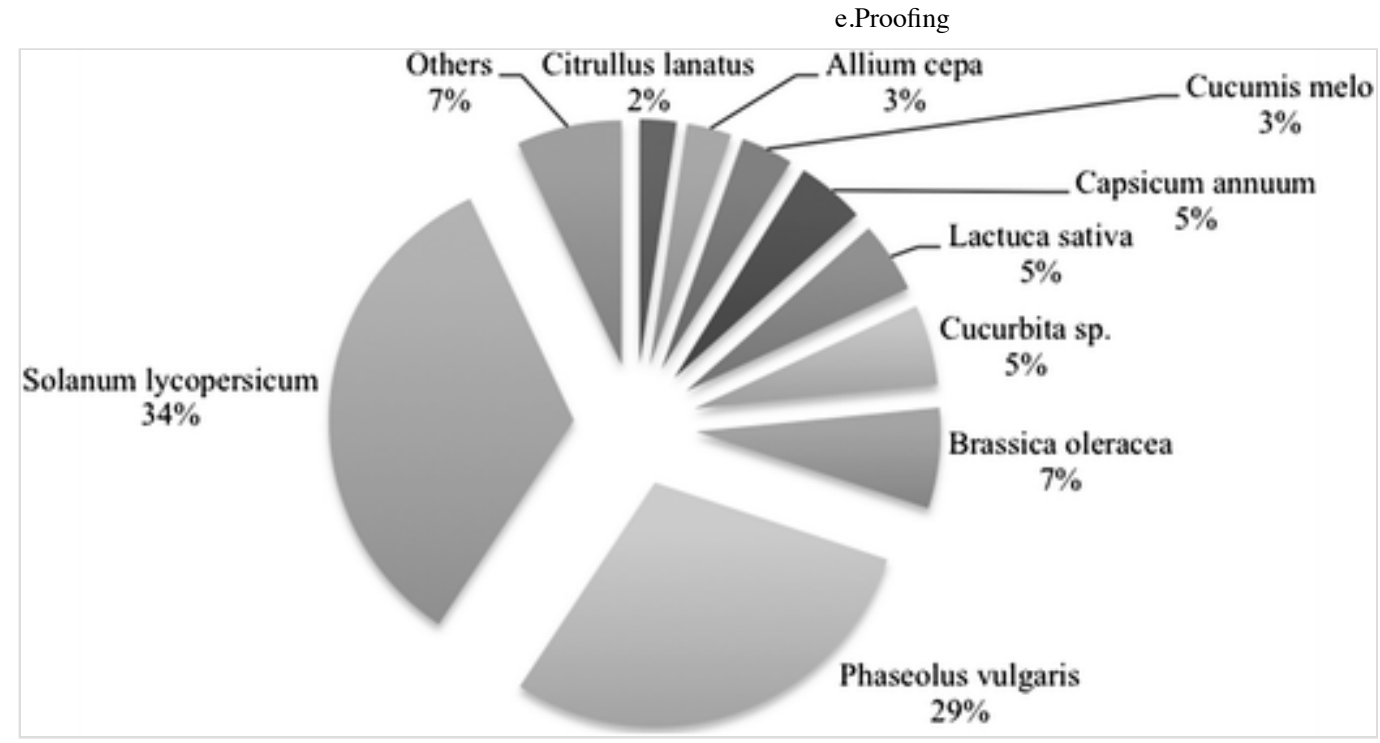

\section{Geographic Distribution of the Accessions and Link with the Activity of the Collecting Institutions}

Geographical information about the collecting site was available in the passport data of $86.3 \%$ of the accessions conserved ex situ, enabling us to map the CGR conserved ex situ in Catalonia (Fig. 2). The CGR conserved in seedbanks is not well distributed across the territory: only 334 of 947 municipalities have 1 or more accessions conserved ex situ (geographical coverage, 35.3\%) (Fig. 2a). In some areas, the number of accessions per municipality is unusually high ( $>40$ accessions), probably due to different factors: (a) the Polytechnic University of Catalonia-Miquel Agustí Foundation intensive germplasm collecting activities for plant breeding programs in specific landraces (e.g., Santa Pau bean in the Garrotxa district (Almirall et al. 2010), Ganxet bean in the Vallès Oriental and Vallès Occidental districts (Sanchez et al. 2008), and Montserrat and Pera Girona tomatoes in the Maresme and La Selva districts (Casals et al. 2010)); (b) the presence of a seedbank in the municipality (e.g., Manresa (54 accessions), where the Esporus seed bank is located); (c) or the presence of an important food market where accessions were collected (e.g., Barcelona, which has no agricultural activity but contributed 47 accessions). Germplasm collections at universities seem to have a higher geographical coverage (22.3\%) (Fig. 2c) than those managed by nonprofit organizations (15.4\%) (Fig. 2d) and those collected directly by the National Inventory (i.e., not duplicates sent by universities or nonprofit organizations) (14.5\%) (Fig. 2b).

Fig. 2.

Geographic distribution of germplasm conserved ex situ in different seed banks: a entire germplasm collection ( $n=2528$ accessions; $86.3 \%$ with geographical data); b National Inventory (solely unique accessions are represented) $(n=765 ; 94.6 \%$ with geographical data); c universities ( $n=1052 ; 82.2 \%$ with geographical data); d 
nonprofit organizations $(n=696 ; 84.5 \%$ with geographical data); e botanical gardens $(n=15 ; 83.3 \%$ with geographical data).

a

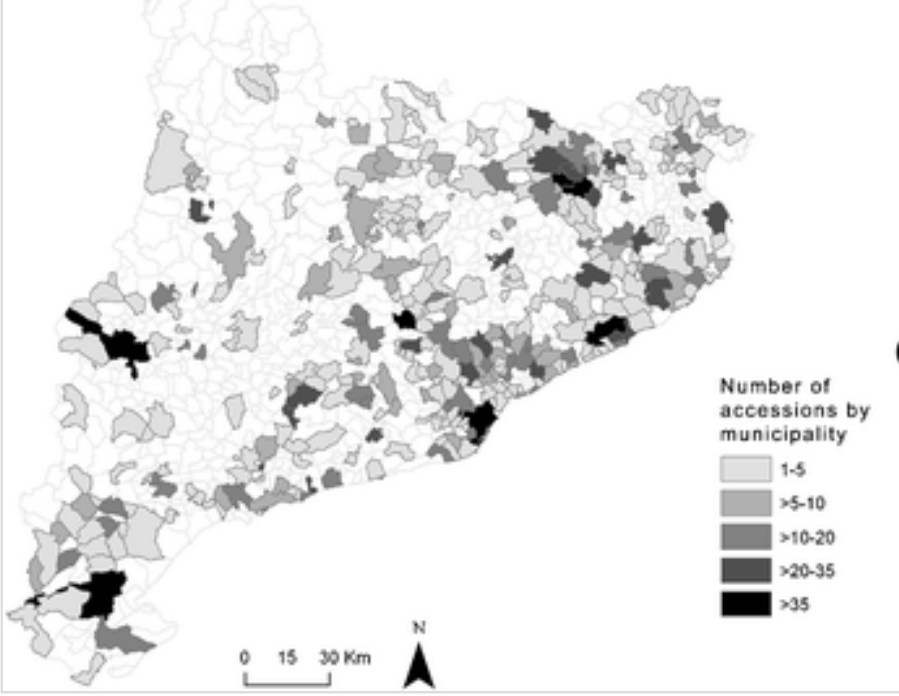

b

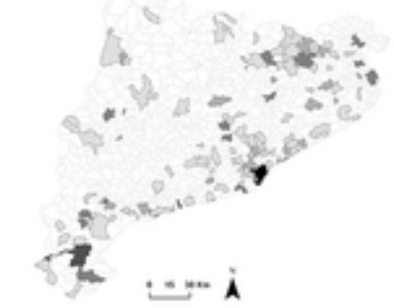

d

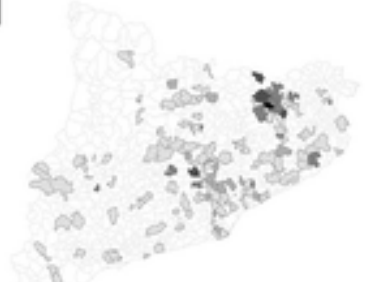

C

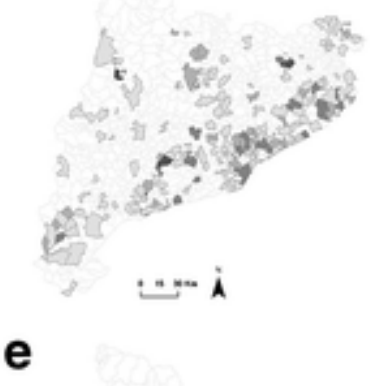

In addition to differing in their contributions to the geographic and genetic richness of the ex situ germplasm collections, actors in the CGR network differ in the other tasks related to conservation (Table 2). The National Inventory has the most secure collection, with a coordinate system of duplicates in different gene banks, equipment adapted for seed storage, and a program for seed regeneration. Universities are also secure, although they focus on specific species, so their contribution to the total CGR conservation system is narrower. Moreover, at universities, intense phenotyping activity ensures that the agricultural and morphological properties of the stored germplasm is well documented. Finally, nonprofit organizations lack security systems (equipment for seed storage, duplicates in different seed banks), so the stored seeds are not protected enough against genetic erosion; nevertheless, they play an important role in raising social awareness and in distributing seeds. So, the different contributions appear related to the different objectives of each institution.

Table 2.

TASKS PERFORMED BY THE DIFFERENT ACTORS IN THE CGR NETWORK IN CATALONIA.

\begin{tabular}{|l|l|l|l|l|}
\hline \multicolumn{1}{|c|}{ Activity } & $\begin{array}{c}\text { National } \\
\text { Inventory }\end{array}$ & Universities & \multicolumn{1}{|c|}{$\begin{array}{c}\text { Nonprofit } \\
\text { organizations }\end{array}$} & $\begin{array}{l}\text { Botanical } \\
\text { Gardens }\end{array}$ \\
\hline Collecting & All & Selective & All & No \\
\hline Characterization & No & Intense & Partial & No \\
\hline Seed regeneration & Yes & Partial & Partial & Yes \\
\hline $\begin{array}{l}\text { Security systems and } \\
\text { optimal conditions of seed } \\
\text { conservation }\end{array}$ & Yes & Yes & No & Yes \\
\hline
\end{tabular}




\begin{tabular}{|l|l|l|l|l|}
\hline \multicolumn{1}{|c|}{ Activity } & $\begin{array}{c}\text { National } \\
\text { Inventory }\end{array}$ & Universities & $\begin{array}{c}\text { Nonprofit } \\
\text { organizations }\end{array}$ & $\begin{array}{c}\text { Botanical } \\
\text { Gardens }\end{array}$ \\
\hline $\begin{array}{l}\text { Send duplicates to the } \\
\text { National Inventory }\end{array}$ & - & Yes & No & No \\
\hline Distribution of seeds & Free & No & Free & Free \\
\hline
\end{tabular}

\section{The New Collecting Mission}

A total of 234 accessions were collected in the four Natura 2000 areas studied (Table 3 ). The most common species collected were tomato (41 accessions, $17.5 \%$ of the total) and common bean (38 accessions, $16.2 \%$ of the total). Accessions from both species were collected in all the areas studied, signaling their broad adaptability (tomato germplasm was collected at sites between 15 and $925 \mathrm{~m}$ a.s.1., and common bean germplasm between 15 and $1215 \mathrm{~m}$ a.s.1.) and farmers' high esteem for landraces of these crops. Another important species collected was dry pea (29 accessions, 12.4\% of the total) (Pisum sativum L.), mainly due to the presence of the "pèsol negre" (black pea) landrace in the mountainous ES5130029 area.

Table 3.

Number AND FREQUENCY OF THE ACCESSIONS COLLECTED IN THE FOUR NATURA 2000 AREAS IN 2011.

\begin{tabular}{|l|l|l|l|}
\hline \multicolumn{1}{|c|}{ Common name } & \multicolumn{1}{|c|}{ Scientific name } & $\begin{array}{c}\text { Accessions } \\
\text { (n) }\end{array}$ & \multicolumn{1}{|c|}{$\begin{array}{c}\text { Frequency } \\
\text { (\%) }\end{array}$} \\
\hline Onion & Allium cepa L. & 3 & 1.3 \\
\hline Dill & Anethum graveolens L. & 2 & 0.9 \\
\hline Asparagus & Asparagus officinalis L. & 1 & 0.4 \\
\hline Chard & Beta vulgaris var.cicla L. & 6 & 2.6 \\
\hline Borage & Borago officinalis L. & 1 & 0.4 \\
\hline Cabbage & Brassica oleracea L. & 12 & 5.1 \\
\hline Pepper & Capsicum annuum L. & 11 & 4.7 \\
\hline Chickpea & Cicer arietinum L. & 7 & 3.0 \\
\hline Endive & Cichorium endivia L. & 3 & 1.3 \\
\hline Chicory & Cichorium intybus L. & 1 & 0.4 \\
\hline Watermelon & $\begin{array}{l}\text { Citrullus lanatus } \text { (Thunb.) Matsum. } \\
\text { \& Nakai }\end{array}$ & 1 & 0.4 \\
\hline Melon & Cucumis melo L. & 15 & 6.4 \\
\hline
\end{tabular}




\begin{tabular}{|c|c|c|c|}
\hline Common name & Scientific name & $\begin{array}{c}\text { Accessions } \\
\text { (n) }\end{array}$ & $\begin{array}{c}\text { Frequency } \\
(\%)\end{array}$ \\
\hline Cucumber & Cucumis sativus L. & 1 & 0.4 \\
\hline Summer squash & Cucurbita pepo L. & 2 & 0.9 \\
\hline Pumpkin & Cucurbita spp. & 19 & 8.1 \\
\hline Lettuce & Lactuca sativa $\mathrm{L}$. & 13 & 5.6 \\
\hline Grass pea & Lathyrus sativus L. & 5 & 2.1 \\
\hline Parsley & Petroselinum crispum L. & 1 & 0.4 \\
\hline Common bean & Phasoleus vulgaris L. & 38 & 16.2 \\
\hline Pea & Pisum sativum L. & 29 & 12.4 \\
\hline $\begin{array}{l}\text { Common golden } \\
\text { thistle }\end{array}$ & Scolymus hispanicus L. & 1 & 0.4 \\
\hline Tomato & Solanum lycopersicum L. & 41 & 17.5 \\
\hline Spinach & Spinacia oleracea L. & 4 & 1.7 \\
\hline Broad bean & Vicia faba L. & 5 & 2.1 \\
\hline \multirow[t]{2}{*}{ Maize } & Zea mays L. & 12 & 5.1 \\
\hline & TOTAL & 234 & 100.00 \\
\hline
\end{tabular}

Accessions from some species were found mainly in a specific area, signaling the adaptation of these species to the site's agroclimatic conditions and traditions. For instance, chickpeas (Cicer arietinum L.) were found mainly in ES5110015 (5 of the 7 accessions collected). In this area, the landrace "cigronet menut" (small chickpea) is highly valued by farmers and consumers. On the other hand, melons (Cucumis melo L.) were found mainly in ES5140011 (13 of the 15 accessions collected). This area historically produced melons for markets in the cities of Barcelona and Tarragona. Interviews with farmers suggest that no single melon variety is especially valued over others in this area; each accession has a different name, some of which suggest specific organoleptic traits (e.g., "meló de pell fina" (thin-skinned melon), "meló d'aroma” (aromatic melon)).

\section{Comparison of the Germplasm Collected in the New Missions with Germplasm Preserved Ex Situ}

Comparison of data from ex situ collections with data obtained in our new collection missions reveals that a high diversity of CGR is still preserved on farm and some of this CGR was probably not captured by previously collecting expeditions. The indicators of species richness (mean values, $\mathrm{S}_{\text {new mission }}=12.8$, 
$\left.\mathrm{S}_{\text {previous missions }}=7.0\right)$, variety richness $\left(\mathrm{V}_{\text {new mission }}=27, \mathrm{~V}_{\text {previous missions }}=11\right)$, and total abundance $\left(\mathrm{A}_{\text {new mission }}=53.8, \mathrm{~A}_{\text {previous missions }}=18.3\right)$ were significantly higher in the newly collected materials than in the ex situ database (Table 4). There were no significant differences in the Shannon-Weaver index (H1) between ex situ and new collections when considering species and accessions within species ( $p=0.1367$, Table 4$)$, mainly because prior field surveys in ES5130029 collected a high number of species $(n=5)$ in relation to the total number of accessions $(n=8)$. Nevertheless, when considering the variety factor, a significant difference (at $p<0.10$ level) was identified both for $\mathrm{H} 2$ (species and variety levels) and for H3 (variety and accession levels). Thus, high variability not yet reflected in seed banks is still present on farm, and this variability is found at both inter- and intra-variety levels.

Table 4.

COMPARISON OF EXISTING EX SITU CGR (PREVIOUS MISSIONS) AND NEWLY COLLECTED ACCESSIONS NATURA 2000 AREAS. A T THE BOTTOM, MEAN VALUES AND SIGNIFICANCE FROM THE ANOVA ANALYSI

\begin{tabular}{|c|c|c|c|c|c|c|c|}
\hline \multirow[b]{2}{*}{$\begin{array}{l}\text { Area of } \\
\text { study }\end{array}$} & \multirow[b]{2}{*}{$\begin{array}{c}\text { Previous } \\
\text { missions/new } \\
\text { mission }\end{array}$} & \multirow[b]{2}{*}{$\begin{array}{l}\text { Species } \\
\text { richness } \\
(\mathrm{S})\end{array}$} & \multirow[b]{2}{*}{$\begin{array}{l}\text { Variety } \\
\text { richness } \\
\text { (V) }\end{array}$} & \multirow[b]{2}{*}{$\begin{array}{c}\text { Total } \\
\text { abundance } \\
\text { (A) }\end{array}$} & \multicolumn{3}{|c|}{ Shannon-Weaver ir } \\
\hline & & & & & $\begin{array}{c}\text { Species } \\
\text { level } \\
\left(\mathrm{H}_{1}\right)^{\mathrm{a}}\end{array}$ & $\begin{array}{c}\text { Species } \\
\text { level } \\
\left(\mathrm{H}_{2}\right)^{b}\end{array}$ & $\mathbf{V}$ \\
\hline ES5130029 & Previous & 5 & 5 & 8 & 1.56 & 1.609 & 1. \\
\hline ES5130029 & New & 8 & 14 & 40 & 1.50 & 1.909 & 1. \\
\hline ES5110015 & Previous & 9 & 12 & 18 & 1.90 & 1.979 & 2. \\
\hline
\end{tabular}

\begin{tabular}{|c|c|c|c|c|c|c|c|}
\hline \multirow[b]{2}{*}{$\begin{array}{l}\text { Area of } \\
\text { study }\end{array}$} & \multirow[b]{2}{*}{$\begin{array}{c}\text { Previous } \\
\text { missions/new } \\
\text { mission }\end{array}$} & \multirow[b]{2}{*}{$\begin{array}{l}\text { Species } \\
\text { richness } \\
(\mathrm{S})\end{array}$} & \multirow[b]{2}{*}{$\begin{array}{c}\text { Variety } \\
\text { richness } \\
\text { (V) }\end{array}$} & \multirow[b]{2}{*}{$\begin{array}{c}\text { Total } \\
\text { abundance } \\
\text { (A) }\end{array}$} & \multicolumn{3}{|c|}{ Shannon-Weaver iI } \\
\hline & & & & & $\begin{array}{l}\text { Species } \\
\text { level } \\
(\mathrm{H})\end{array}$ & $\begin{array}{l}\text { Species } \\
\text { level } \\
\text { (H ) }\end{array}$ & $\begin{array}{c}\mathbf{V} \\
1\end{array}$ \\
\hline ES5110015 & New & 17 & 39 & 80 & 2.33 & 2.415 & 3. \\
\hline ES5140019 & Previous & 2 & 2 & 3 & 0.64 & 0.693 & 0 \\
\hline ES5140019 & New & 8 & 16 & 26 & 1.74 & 1.906 & 2. \\
\hline ES5140011 & Previous & 12 & 25 & 44 & 2.10 & 2.422 & 2. \\
\hline ES5140011 & New & 18 & 39 & 69 & 2.55 & 2.684 & 3. \\
\hline \multirow[t]{2}{*}{$\begin{array}{l}\text { Mean } \\
\text { values }\end{array}$} & Previous & 7.0 & 11 & 18.3 & 1.55 & 1.676 & 1. \\
\hline & New & 12.8 & 27 & 53.8 & 2.03 & 2.228 & 2. \\
\hline$p$ value & & 0.0125 & 0.0254 & 0.0294 & 0.1367 & 0.0897 & 0 . \\
\hline
\end{tabular}


${ }^{b} \mathrm{H}_{2}=$ considering species and variety levels

${ }^{c} \mathrm{H}_{3}=$ considering variety and accession levels

Finally, we selected the most important landraces (i.e., those with a strong presence in markets and cuisine) to compare the number of accessions found in the new field survey with the number previously stored in seed banks (Table 5). Research groups' previous efforts to collect intra-varietal genetic variability for some landraces have had an important impact. For instance, "Ganxet" bean and "Penjar" tomatoes were highly represented in germplasm banks (388 and 361 accessions, respectively), and the number of newly collected accessions (10 and 11 , respectively) was similar to those previously collected in the same areas (6 and 13, respectively). Nevertheless, some important landraces were not well represented in the gene banks; for instance, few accessions of "col brotonera" (sprouting broccoli) (Brassica oleracea L.), "blat de moro d'escairar" (Zea mays L.), "cigronet de l'Anoia" (Cicer arietinum L.), and "de la Creu," "del Benach," and "Poma/Pometa" tomato landraces were present in ex situ collections, so the newly collected materials will help represent the intravarietal genetic diversity of these landraces considerably.

\section{Table 5.}

A COMPARISON OF THE EX SITU ACCESSIONS IN SEED BANKS AND THE ACCESSIONS COLLECTED IN THE RECENT CAMPAIGN IN FOUR NATURA 2000 AREAS FOR A GROUP OF SELECTED LANDRACES.

\begin{tabular}{|l|l|l|l|}
\hline \multicolumn{1}{|c|}{ Local name } & \multicolumn{1}{|c|}{ Scientific name } & \multicolumn{1}{|c|}{$\begin{array}{c}\text { New collecting } \\
\text { mission }\end{array}$} & \multicolumn{1}{|c|}{$\begin{array}{c}\text { Previously collected } \\
\text { accessions }\end{array}$} \\
\hline $\begin{array}{l}\text { Blat de moro } \\
\text { d'escairar }\end{array}$ & Zea mays L. & 4 & 2 \\
\hline $\begin{array}{l}\text { Cigronet de } \\
\text { l'Anoia }\end{array}$ & Cicer arietinum L. & 4 & 1 \\
\hline Col brotonera & $\begin{array}{l}\text { Brassica oleracea } \\
\text { L. }\end{array}$ & 8 & 0 \\
\hline $\begin{array}{l}\text { Enciam negre } \\
\text { Lactuca sativa L. }\end{array}$ & 3 & 0 \\
\hline $\begin{array}{l}\text { Escarola cabell } \\
\text { d'àngel }\end{array}$ & $\begin{array}{l}\text { Cichorium endivia } \\
\text { L. }\end{array}$ & 3 & 0 \\
\hline $\begin{array}{l}\text { Mongeta del } \\
\text { Ganxet }\end{array}$ & $\begin{array}{l}\text { Phaseolus } \\
\text { vulgaris } \text { L. }\end{array}$ & 10 & 6 \\
\hline Pèsol negre & Pisum sativum L. & 21 & 4 \\
\hline $\begin{array}{l}\text { Tomàquet de } \\
\text { Penjar }\end{array}$ & $\begin{array}{l}\text { Solanum } \\
\text { lycopersicum L. }\end{array}$ & 11 & 13 \\
\hline
\end{tabular}




\begin{tabular}{|l|l|l|l|}
\hline \multicolumn{1}{|c|}{ Local name } & \multicolumn{1}{|c|}{ Scientific name } & $\begin{array}{c}\text { New collecting } \\
\text { mission }\end{array}$ & $\begin{array}{c}\text { Previously collected } \\
\text { accessions }\end{array}$ \\
\hline $\begin{array}{l}\text { Tomàquet del } \\
\text { Benach }\end{array}$ & $\begin{array}{l}\text { Solanum } \\
\text { lycopersicum L. }\end{array}$ & 2 & 0 \\
\hline $\begin{array}{l}\text { Tomàquet de la } \\
\text { Creu }\end{array}$ & $\begin{array}{l}\text { Solanum } \\
\text { lycopersicum L. }\end{array}$ & 2 & 2 \\
\hline $\begin{array}{l}\text { Tomàquet } \\
\text { Poma/Pometa }\end{array}$ & $\begin{array}{l}\text { Solanum } \\
\text { lycopersicum L. }\end{array}$ & 2 & 1 \\
\hline
\end{tabular}

\section{Discussion}

Increasing social awareness about genetic erosion of local landraces has led to various initiatives at national, regional, and local levels to collect and conserve seeds of these varieties. International research centers (mainly in the 1970s and 1980s) (Thormann et al. 2012) and nonprofit organizations and universities (mainly after 2000) have stored hundreds of accessions in seed banks. So, it is necessary to rationalize and prioritize further efforts devoted to collecting and conserving seeds of landraces/old varieties.

In Catalonia, presented here as a case study, of the total of 3568 accessions filed in seed banks, 2931 are unique accessions. Most of these (2121 accessions) are managed by nonprofit organizations or universities without regulated systems to maintain seeds in the long term. Importantly, only $21.7 \%$ of these accessions are present as duplicates in the National Inventory, making the long-term availability of these seeds uncertain. Furthermore, some landraces are overrepresented in the ex situ collections because breeding programs developed by Polytechnic University of Catalonia-Miquel Agustí Foundation have extensively collected seeds of "Ganxet" (388 accessions) (Casañas et al. 1997; Casañas et al. 1999) and "Santa Pau" beans (48 accessions) (Almirall et al. 2010), and of "Penjar" (361 accessions) (Casals et al. 2012), "Montserrat" (96 accessions) (Casals et al. 2011), and "Pera de Girona" tomatoes (61 accessions) (Casals et al. 2010). Given the high costs of ex situ conservation (Li and Pritchard 2009), studies are underway to characterize the genetic variability within these varieties at the agricultural, morphological, organoleptic, chemical, and DNA levels to build core collections of these varieties (i.e., a limited set $(5-20 \%$ of the total collection) of accessions chosen to represent the genetic spectrum in the whole collection (van Hintum et al. 2000)). Characterization will make space in seed banks by reducing the number of accessions conserved ex situ without losing genetic variability, as has already been done for example with Spanish common bean genetic resources (Pérez-Vega et al. 2009; Rivera et al. 2016). 
Our results show that the geographical coverage of the seed banks is low as only $35.3 \%$ of the municipalities in Catalonia are represented. Considering the high agroclimatic variability in Catalonia and the relationship between ecogeographical factors and patterns of plant genetic variation (Peeters et al. 1990; Russell et al. 2016), the low geographical coverage of seed banks is an important shortcoming in CGR conservation in this area. This irregularity is due to various factors, including the different interests of the institutions involved in CGR conservation, the location of the seed banks, and the lack of an integral plan for the conservation and use of CGR in Catalonia. GIS technology is increasingly used in germplasm collection missions (Jarvis et al. 2005), and GIS data developed in this study can be used to guide new collection missions.

Tomatoes and common beans were the species with the most accessions collected in our field surveys and are also the species with the most accessions in the ex situ collections. These results are not surprising, as tomatoes and beans are the species most frequently conserved by farmers in the Mediterranean basin (Montesano et al. 2012; Thomas et al. 2012). Farmers value landraces from these species for different reasons. Tomato landraces' organoleptic profile is considered superior to that of modern varieties (Casals et al. 2011; Sinesio et al. 2007), and the "Penjar" landrace is valued in Catalonia for its long shelf life (Casals et al. 2012). Common beans have historically been appreciated for their nutritive properties and for their ability to be stored, and they are key ingredients in many traditional Catalan dishes.

One of the main shortcomings of the ex situ conservation system in Catalonia is that the diversity of species and varieties are not well represented in the ex situ collections. Our results in the model areas show that diversity calculated at species (species richness (S) and Shannon-Weaver index (H2)) and variety levels (variety richness (V) and Shannon-Weaver index (H3)) are significantly higher on farm than ex situ (Table 4). Thus, the representation of the diversity (at species, variety, and intra-varietal levels) in ex situ collections does not accurately reflect what is still cultivated on farm. These differences are probably due to incomplete collecting activities in previous missions. In the present project, we spent 3 days collecting seeds in each municipality. This highly intensive scheme enabled us to capture nearly all genetic resources grown on farm in these areas, making it possible for us to compare ex situ (what is filed in seed banks) with in situ (what we have collected) collections. Nevertheless, as the collection missions took place at different times, a fraction of the differences between ex situ and in situ may be due to the introduction of new varieties through immigration or crosses and selection (although an unknown number have also been lost in the meanwhile). More importantly, for some economically 
relevant landraces, the number of accessions conserved ex situ is very low (Table 5). Apart from genetic erosion issues, this can be an important gap for farmers interested in cultivating these varieties for market-driven productions in the future. These results show that further efforts to capture the genetic variability among vegetable CGR still cultivated, if planned with stricter methods and carried out with greater efficiency, can yield valuable results. Furthermore, our analysis underlines the need to obtain phenotypic or molecular data of accessions conserved ex situ in order to identify possible homonymies (i.e., accessions with similar varietal names but with different genetic fingerprints) and synonymies (i.e., duplicates).

The genetic erosion rate in the last century has been high in all crops (Hammer and Teklu 2008; van de Wouw et al. 2010) and is a major concern for agriculture. For instance, the genetic erosion in cereals (excluding maize) has been estimated from 80 to $100 \%$ (Hammer et al. 1996; Hammer and Laghetti 2005). Although our study did not specifically target cereals, our mission collected only two accessions of wheat (Triticum aestivum L.) and no accessions of other cereals important in our area such as barley (Hordeum vulgare L.) or oats (Avena sativa L.). By contrast, our results show that although landraces of vegetables and pulses have been replaced by modern varieties (nearly $100 \%$ ) in market-driven productions, the replacement rate in vegetable gardens is much lower and genetic diversity has been preserved (and probably created de novo). In fact, only one landrace mentioned by farmers could not be found during our missions; this landrace ("safranòria," a red carrot previously cultivated in ES5140011 area) was also absent from the ex situ collections and can be considered extinct. However, farmers still conserve seeds of the remaining landraces with at least some recognizable traits.

The present study shows that although germplasm banks conserve significant genetic variability, the real genetic diversity found in situ is even greater and could increase the genetic diversity held ex situ. So, we propose the following actions to increase the efficiency of the CGR conservation system:

(a) A single institution should be in charge of analyzing and coordinating publicly funded CGR network activities. This institution should guide future prospection missions to unexplored areas and/or focus on specific species/varieties that are poorly represented in ex situ collections.

(b) All the CGR collected with public funding should be stored as duplicates in the National Inventory. A clear material transfer agreement (MTA) should be reached with farmers in order to protect their rights on possible agricultural innovations developed from these materials. 
(c) Universities and botanical gardens should take advantage of their collecting activities to also collect species that are not of particular interest for their plant breeding or conservation programs.

(d) A coordinated system of phenotyping using consensus descriptors should be created to document the agricultural and morphological characteristics of stored accessions to enhance their use.

(e) Phenotypic and genotypic data should be used to detect duplicates and to develop core collections to reduce the number of accessions that need to be stored.

In summary, our results show that better organization and coordination between major and minor actors involved in the CGR conservation network are needed to increase the efficiency and coverage of the collections and the study of established and newly emerging landraces.

\section{Acknowledgements}

We are grateful to the managers of the germplasm banks that have collaborated in this study. This work was partly funded by grants of Fundación Biodiversidad via the project "Recovering, through use, agrobiodiversity in natural areas of Natura 2000 network."

\section{Literature Cited}

Almirall, A., L. Bosch, R. Romero del Castillo, A. Rivera and F. Casañas. 2010. 'Croscat' common bean (Phaseolus vulgaris L.), a prototypical cultivar within the 'Tavella Brisa' type. HortScience 45(3): 432-433.

Berg, T. 2009. Landraces and folk varieties: A conceptual reappraisal of terminology. Euphytica 166(3): 423-430.

Calvet-Mir, L., M. Calvet-Mir, L. Vaqué-Nuñez, and V. Reyes-García. 2011. Landraces in situ conservation: A case study in high-mountain home gardens in vall fosca, catalan pyrenees, iberian peninsula. Economic Botany 65(2): 146.

Casals, J., L. Bosch, F. Casanas, J. Cebolla, and F. Nuez. 2010. Montgri, a cultivar within the montserrat tomato type. HortScience 45(12): 1885-1886. 
Casals, J., L. Pascual, J. Canizares, J. Cebolla-Cornejo, F. Casanas, and F. Nuez. 2011. The risks of success in quality vegetable markets: possible genetic erosion in Marmande tomatoes (Solanum lycopersicum L.) and consumer dissatisfaction. Scientia Horticulturae 130(1): 78-84.

Casals, J., L. Pascual, J. Canizares, J. Cebolla-Cornejo, F. Casanas, and F. Nuez. 2012. Genetic basis of long shelf life and variability into Penjar tomato. Genetic Resources and Crop Evolution 59(2): 219-229.

Casañas, F., L. Bosch, E. Sánchez, R. Romero del Castillo, J. Valero, M. Baldi, J. Mestres, and F. Nuez. 1997. Collecting, conservation and variability of Ganxet common bean (Phaseolus vulgaris L.). Plant genetic resources Newsletter 112: 105-106.

Casañas, F., L. Bosch, M. Pujolà, E. Sánchez, X. Sorribas, M. Baldi, and F. Nuez. 1999. Characteristics of a common bean landrace (Phaseolus vulgaris L.) of great culinary value and selection of a commercial inbred line. Journal of the Science of Food and Agriculture 79(5): 693-698.

Galluzzi, G. and I. López Noriega. 2014. Conservation and use of genetic resources of underutilized crops in the Americas - a continental analysis. Sustainability 6(2): 980-1017.

Gepts, P. 2006. Plant genetic resources conservation and utilization. Crop Science 46(5): 2278-2292.

Hammer, K. and G. Laghetti. 2005. Genetic erosion - examples from Italy. Genetic Resources and Crop Evolution 52(5): 629-634.

Hammer, K. and Y. Teklu. 2008. Plant genetic resources: selected issues from genetic erosion to genetic engineering. Journal of Agriculture and Rural Development in the Tropics and Subtropics 109(1): 15-50.

Hammer, K., H. Knupffer, L. Xhuveli, and P. Perrino. 1996. Estimating genetic erosion in landraces - two case studies. Genetic Resources and Crop Evolution 43(4): 329-336.

Hancock, J.F. 2004. Plant evolution and the origin of crop species.

Cambridge: CABI Publishing. 
van Hintum, T.J., A.H.D. Brown, C. Spillane, and T. Hodkin. 2000. Core collections of plant genetic resources. Rome: IPGRI.

Jarvis, A., K. Williams, D. Williams, L. Guarino, P.J. Caballero, and G. Mottram. 2005. Use of GIS for optimizing a collecting mission for a rare wild pepper (Capsicum flexuosum Sendtn.) in Paraguay. Genetic Resources and Crop Evolution 52(6): 671-682.

Jarvis, D.I., A.H.D. Brown, P.H. Cuong, L. Collado-Panduro, L. LatournerieMoreno, S. Gyawali, T. Tanto, M. Sawadogo, I. Mar, M. Sadiki, N.T.-N. Hue, L. Arias-Reyes, D. Balma, J. Bajracharya, F. Castillo, D. Rijal, L. Belqadi, R. Ranag, S. Saidi, J. Ouedraogo, R. Zangre, K. Rhrib, J.L. Chavez, D.J. Schoen, B. Sthapit, P. De Santis, C. Fadda, and T. Hodgkin. 2008. A global perspective of the richness and evenness of traditional crop-variety diversity maintained by farming communities. Proceedings of the National Academy of Sciences of the United States of America 105 (14): 5326-5331.

Laghetti, G., F. Martignano, V. Falco, S. Cifarelli, T. Gladis, and K. Hammer. 2005. "Mugnoli": A neglected race of Brassica oleracea L. from Salento (Italy). Genetic Resources and Crop Evolution 52(5): 635-639.

Li, D.Z. and H.W. Pritchard. 2009. The science and economics of ex situ plant conservation. Trends in Plant Science 14 (11): 614-621.

Maxted, N., M. Scholten, R. Codd, and B. Ford-Lloyd. 2007. Creation and use of a national inventory of crop wild relatives. Biological Conservation 140 (1-2): 142-159.

Montesano, V., D. Negro, G. Sarli, G. Logozzo, and P. Spagnoletti Zeuli. 2012. Landraces in inland areas of the Basilicata Region, Italy: Monitoring and perspectives for on farm conservation. Genetic Resources and Crop Evolution 59(5): 701-716.

Ostermann, O.P. 1998. The need for management of nature conservation sites designated under Natura 2000. Journal of Applied Ecology 35(6): 968-973.

Peeters, J.P., H.G. Wilkes, and N.W. Galwey. 1990. The use of ecogeographical data in the exploitation of variation from gene banks. Theoretical and Applied Genetics 80(1): 110-112.

Pérez-Vega, E., A. Campa, L. De la Rosa, R. Giraldez, and J.J. Ferreira. 2009. Genetic diversity in a core collection established from the main bean 
genebank in Spain. Crop Science 49(4): 1377-1386.

Portis, E., M. Baudino, F. Magurno, and S. Lanteri. 2012. Genetic structure and preservation strategies of autochthonous vegetable crop landraces of North-Western Italy. Annals of Applied Biology 160(1): 76-85.

Prada, D. 2009. Molecular population genetics and agronomic alleles in seed banks: searching for a needle in a haystack? Journal of Experimental Botany 60(9): 2541-2552.

Rivera, A., P.A. Casquero, S. Mayo, A. Almirall, M. Plans, J. Simó, R. Romero del Castillo, and F. Casañas. 2016. Culinary and sensory traits diversity in the Spanish core collection of common beans (Phaseolus vulgaris L.). Spanish Journal of Agricultural Research 14(1): e0701.

Russell, J., M. Mascher, I.K. Dawson, S. Kyriakidis, C. Calixto, F. Freund, M. Bayer, I. Milne, T. Marshall-Griffiths, S. Heinen, A. Hofstad, R. Sharma, A. Himmelbach, M. Knauft, M. van Zonneveld, J.W.S. Brown, K. Schmid, B. Kilian, G.J. Muehlbauer, N. Stein, and R. Waugh. 2016. Exome sequencing of geographically diverse barley landraces and wild relatives gives insights into environmental adaptation. Nature Genetics 48: 1024-1030.

Sanchez, E., A. Sifres, F. Casañas, and F. Nuez. 2008. The endangered future of organoleptically prestigious European landraces: ganxet bean (Phaseolus vulgaris L.) as an example of a crop originating in the Americas. Genetic Resources and Crop Evolution 55(1): 45-52.

Simó, J., R.R. del Castillo, A. Almirall, and F. Casañas. 2012. 'Roquerola' and 'Montferri', First Improved Onion (Allium cepa L.) Cultivars for "Calçots" Production. HortScience 47(6): 801-802.

Sinesio, F., E. Moneta, and M. Peparaio. 2007. Sensory characteristics of traditional field grown tomato genotypes in Southern Italy. Journal of Food Quality 30(6): 878-895.

Tanksley, S.D. and S.R. McCouch. 1997. Seed banks and molecular maps: unlocking genetic potential from the wild. Science 277(5329): 1063-1066.

Thomas, K., R. Thanopoulos, H. Knüpffer, and P. Bebeli. 2012. Plant genetic resources of Lemnos (Greece), an isolated island in the Northern Aegean Sea, with emphasis on landraces. Genetic Resources and Crop Evolution 59(7): 1417-1440. 
Thormann, I., H. Gaisberger, F. Mattei, L. Snook, and E. Arnaud. 2012.

Digitization and online availability of original collecting mission data to improve data quality and enhance the conservation and use of plant genetic resources. Genetic Resources and Crop Evolution 59(5): 635-644.

Veteläinen, M. and N. Maxted. 2009. European landraces: on-farm conservation, management and use. Rome: Bioversity International.

van de Wouw, M., C. Kik, T. van Hintum, R. van Treuren, and B. Visser. 2010. Genetic erosion in crops: Concept, research results and challenges. Plant Genetic Resources-Characterization and Utilization 8(1): 1-15.

Zeven, A.C. 1998. Landraces: a Review of Definitions and Classifications. Euphytica 104(2): 127-139. 